\title{
Temperature-dependent expression of immune-relevant genes in rainbow trout following Yersinia ruckeri vaccination
}

\author{
Martin K. Raida, Kurt Buchmann* \\ Department of Veterinary Pathobiology, Section of Fish Diseases, Faculty of Life Sciences, The University of Copenhagen, \\ Stigbøjlen 7, 1870 Frederiksberg C., Denmark
}

\begin{abstract}
The gene expression of immune-relevant genes in rainbow trout Oncorhynchus mykiss following vaccination with a bacterin of Yersinia ruckeri, a bacterial pathogen causing enteric red mouth disease (ERM), was investigated at 5, 15, and $25^{\circ} \mathrm{C}$. Rainbow trout were immunized by i.p. injection of a water-based Y. ruckeri (serotype O1) bacterin, and gene expression profiles were compared to control groups injected with phosphate buffered saline (PBS). Blood and tissue samples (spleen and head kidney) were taken for subsequent analysis using solid phase enzyme-linked immunosorbent assay (ELISA) and real-time PCR, respectively. The up-regulation of cytokine genes was generally faster and higher at high water temperature, with major expression at $25^{\circ} \mathrm{C}$. The proinflammatory cytokine interleukin (IL)-1 $\beta$ and interferon (IFN)- $\gamma$ were significantly up-regulated in all immunized groups, whereas the cytokine IL-10 was only up-regulated in fish kept at 15 and $25^{\circ} \mathrm{C}$. The gene encoding the C5a (anaphylatoxin) receptor was expressed at a significantly increased level in both head kidney and spleen of immunized fish. The secreted immunoglobulin M (IgM)-encoding gene was significantly up-regulated in the head kidney of immunized trout reared at $25^{\circ} \mathrm{C}$, and a positive correlation $(\mathrm{r}=0.663)$ was found between gene expression of secreted IgM in the head kidney and Y. ruckeri-specific antibodies in plasma measured by ELISA. However, no regulation of the teleost specific immunoglobulin $\mathrm{T}$ (IgT), which was generally expressed at a much lower level than IgM, could be detected. The study indicated that expression of both innate and specific adaptive immune-response genes are highly temperature-dependent in rainbow trout.
\end{abstract}

KEY WORDS: Rainbow trout $\cdot$ Immune-relevant genes $\cdot$ Yersinia ruckeri $\cdot$ Vaccination $\cdot$ Temperature Resale or republication not permitted without written consent of the publisher

\section{INTRODUCTION}

The bacterial pathogen Yersinia ruckeri causes enteric red mouth disease (ERM) in rainbow trout Oncorhynchus mykiss and is considered a severe pest in traditional trout farming. However, the disease can be controlled by vaccination, which is widely applied in modern aquaculture. A crude bacterin, based on formalin-killed bacteria, is efficacious by all routes of administration (intra-peritoneal [i.p.], oral, bath, immersion, spray; Johnson \& Amend 1983, Stevenson 1997). The empirical knowledge of Y. ruckeri vaccination makes it an excellent model system for investigation of anti-bacterial immunity in rainbow trout
(Stevenson 1997), but despite the high degree of protection induced by the vaccination, the mechanisms involved in the response to vaccine administration are still less well elucidated. In addition, the effects of temperature on induced immunity are largely unknown in this pathogen-host system. Therefore, we investigated the reactions in rainbow trout at 5,15 , and $25^{\circ} \mathrm{C}$, temperatures spanning extremes of the physiological range of this fish species including a low sub-optimal level via the physiological optimum to the near lethal temperature (Matthews \& Berg 1997). Even though immersion vaccination with $Y$. ruckeri bacterin is effective, injection delivery of the bacterin results in a superior protection against ERM compared to other 
routes of administration (Johnson \& Amend 1983). Further, i.p.-injected Y. ruckeri bacterin induces inflammation and influx of neutrophils and macrophages into the peritoneal cavity (Afonso et al. 1998, 1999). Therefore, we focused on the gene expression in immunerelevant organs initiated by i.p.-delivered $Y$. ruckeri bacterin. Fish were immunized using a vaccine without adjuvant, because protection is considered excellent even in the absence of adjuvant (Cossarini-Dunier 1986). Thus, the measured gene activation was due to injection of the bacterial antigen and was independent of reactions elicited by an adjuvant. Samples (head kidney and spleen) were analyzed for gene expression (quantitative real-time PCR using Taq-Man probes) of cytokines (interleukin [IL]-1 $\beta$, IL-10, transforming growth factor [TGF], interferon [IFN]- $\gamma$ ), immunoglobulins (IgM, IgT), and cellular receptors (major histocompatibility complex [MHC] II, TcR, C5aR), which involve both humoral and cellular factors in trout. To compare the expression of immunoglobulin genes to functional molecules in the host, the specific antibody titers of host plasma samples were evaluated by ELISA.

\section{MATERIALS AND METHODS}

Fish and rearing conditions. Out-bred rainbow trout, hatched and reared under pathogen-free conditions (Bornholm Salmon Hatchery, Nexø, Bornholm, Denmark), were brought to the experimental university facility upon reaching a total body weight of 10 to $15 \mathrm{~g}$. They were then maintained (at a 12:12 $\mathrm{h}$ light:dark cycle) in aerated (>100\% oxygen saturation) tap water at 12 to $13^{\circ} \mathrm{C}$ in $100 \mathrm{l}$ aquaria with biofilters (Eheim, Germany) and fed commercial trout feed (BioMar, Denmark) until use (at a body weight of 50 to $80 \mathrm{~g}$ ). The water temperature was then slowly changed $\left(1^{\circ} \mathrm{C} \mathrm{d}^{-1}\right)$ until the fish were adapted to constant water temperatures at 5,15 , and $25^{\circ} \mathrm{C}$. Fish were kept at these temperatures (ranging from a sub-optimal level via the physiological optimum to the near-lethal limit of trout) for $3 \mathrm{wk}$ before immunization. Vaccinated fish and control fish were kept in the same tank but separated by a mesh screen to secure exactly the same environmental parameters for both groups.

Immunization and sampling. Rainbow trout were immunized with Yersinia ruckeri (serotype O1) bacterin (Pharmaq AS, Norway) by i.p. injection (100 $\mu \mathrm{l}$ fish $^{-1}$ ). The solvent of the bacterin was phosphate buffered saline (PBS), and no traces of inactivating substances (formalin) could be detected according to the manufacturer. Control groups were injected i.p. with $100 \mu \mathrm{l}$ PBS (pH 7.2). Five immunized and control fish were sampled (at each temperature) at 0, 4, 8, 24,
$48 \mathrm{~h}$ and 7,14 , and $21 \mathrm{~d}$ post-immunization (dpi). Fish were killed by an overdose of MS-222 (100 $\mathrm{mg} \mathrm{l}^{-1}$; Sigma-Aldrich). Blood was sampled from the vena caudalis using heparinized syringes and immediately centrifuged at $1500 \times g$ for $5 \mathrm{~min}\left(4^{\circ} \mathrm{C}\right)$; the plasma was then recovered and stored at $-20^{\circ} \mathrm{C}$. The spleens and head kidneys (approximately equal amounts of tissue) were sampled aseptically and immediately transferred to RNA-later (Sigma-Aldrich), pre-stored at $4^{\circ} \mathrm{C}(24 \mathrm{~h})$, and then stored at $-20^{\circ} \mathrm{C}$ until isolation of RNA. When comparing groups for immunological parameters, the vaccinated and control groups sampled at the same time points were compared.

Isolation of total RNA and cDNA synthesis. Homogenization of tissue was done by sonication on ice (Sonicator Ultrasonic Liquid Processor Model XL 2020, Heat Systems) and total RNA isolated using RTN350 (Sigma-Aldrich). RNA quantity and quality were checked by OD260/280 measurements (BIORAD SmartSpec ${ }^{\mathrm{TM}}$ 3000). cDNA synthesis was performed on exactly the same amounts of mRNA following adjustment of concentrations in all samples. Random hexamer primed reverse transcription reactions, which were performed from 400 ng DNAse (DNase I, SigmaAldrich) treated total RNA in a $20 \mu$ l setup using TaqMan ${ }^{\circledR}$ Reverse Transcription reaction following the manufacturer's instructions (Applied Biosystems). RTreactions lacking reverse transcriptase (RT minus) but not RNA were also performed to verify that the samples did not contain genomic DNA. The synthetized cDNA samples were diluted 1:10 in MilliQ $\mathrm{H}_{2} \mathrm{O}$ and stored at $-20^{\circ} \mathrm{C}$.

Real-time PCR assay. Quantitative PCR assays were performed using a Stratagene MX3000PTM real-time PCR system. Based on available GenBank sequences (www.ncbi.nlm.nih.gov/), primers and dual-labeled TaqMan ${ }^{\circledR}$ probes conjugated with $5^{\prime}$ HEX or CY 5 and a 3' BHQ1 or BHQ2 were designed using Primer3 software (http://frodo.wi.mit.edu/cgibin/primer3/primer3_www.cgi). Primers and probes were analyzed for hairpin structure, self- and heterodimers in OligoAnalyzer 3.0 (www.idtdna.com/ analyzer/Applications/OligoAnalyzer/Default.aspx). Primers and probes are shown in Table 1. All primers and probes were HPLC-purified (Sigma-Genosys). The primers were optimized according to $\mathrm{MgCl}_{2}$ concentrations. Melting curve analyses of the primers were conducted with a SYBR Green based RQ-PCR assay, and only primer pairs with a single melting peak were used. To assess that the primer and probe pairs were quantitative within the working range, serial dilutions in 10-fold increments of cDNA were used. The cycling conditions were $94^{\circ} \mathrm{C}$ for $2 \mathrm{~min}$ followed by 40 cycles of $94^{\circ} \mathrm{C}$ for $30 \mathrm{~s}$ and $60^{\circ} \mathrm{C}$ for $1 \mathrm{~min}$. Wells contained $6.25 \mu \mathrm{l}$ of $2 \times$ JumpStartTM 
Table 1. Oncorhynchus mykiss. Real time PCR expression of immune relevant genes. Primers (Fwd and Rev: forward and reverse, respectively) and probe sets including their GenBank accession numbers, product sizes, sequences, and qPCR efficiency. EF: elongation factor; Ig: immunoglobulin (IgM $\mu 4$ is secreted, IgT is secreted and membrane-bound); MHC II: major histocompatibility complex II ( $\beta$ chain); IL: interleukin; TGF: transforming growth factor; TcR: T-cell receptor ( $\beta$ chain); C5aR: C5a receptor; IFN: interferon

\begin{tabular}{|c|c|c|c|c|c|}
\hline Gene & Acc. no. & $\begin{array}{l}\text { Product } \\
\text { size (bp) }\end{array}$ & Primer & Probe & $\begin{array}{l}\text { qPCR } \\
\text { eff. }(\%)\end{array}$ \\
\hline EF1- $\alpha$ & AF498320 & 63 & $\begin{array}{l}\text { Fwd: ACCCTCCTCTTGGTCGTTTC } \\
\text { Rev: TGATGACACCAACAGCAACA }\end{array}$ & GCTGTGCGTGACATGAGGCA & 100.0 \\
\hline $\operatorname{IgM} \mu 4$ & S63348 & 72 & $\begin{array}{l}\text { Fwd: CTTGGCTTGTTGACGATGAG } \\
\text { Rev: GGCTAGTGGTGTTGAATTGG }\end{array}$ & TGGAGAGAACGAGCAGTTCAGCA & 98.4 \\
\hline $\operatorname{IgT}$ & AY870265 & 72 & $\begin{array}{l}\text { Fwd: AGCACCAGGGTGAAACCA } \\
\text { Rev: GCGGTGGGTTCAGAGTCA }\end{array}$ & AGCAAGACGACCTCCAAAACAGAAC & 98.5 \\
\hline MHC II & AF115533 & 67 & $\begin{array}{l}\text { Fwd: TGCCATGCTGATGTGCAG } \\
\text { Rev: GTCCCTCAGCCAGGTCACT }\end{array}$ & CGCCTATGACTTCTACCCCAAACAAAT & 101.1 \\
\hline IL-10 & AB118099 & 70 & $\begin{array}{l}\text { Fwd: CGACTTTAAATCTCCCATCGAC } \\
\text { Rev: GCATTGGACGATCTCTTTCTTC }\end{array}$ & CATCGGAAACATCTTCCACGAGCT & 101.7 \\
\hline TGF $\beta$ & X99303 & 75 & $\begin{array}{l}\text { Fwd: TCTGAATGAGTGGCTGCAAG } \\
\text { Rev: GGTTTCCCACAATCACAAGG }\end{array}$ & CTGGAGAGGAGCAGGGATTCCAAT & 98.2 \\
\hline TcR & AF329700 & 73 & $\begin{array}{l}\text { Fwd: TCACCAGCAGACTGAGAGTCC } \\
\text { Rev: AAGCTGACAATGCAGGTGAATC }\end{array}$ & CCAATGAATGGCACAAACCAGAGAA & 96.6 \\
\hline C5aR & AY438032 & 61 & $\begin{array}{l}\text { Fwd: ACGCACCTTGAGGGTCATT } \\
\text { Rev: CAGTGGAAACCAGCACAGG }\end{array}$ & TTGCCGTGTCGCTGAGCTTCTT & 101.9 \\
\hline IFN- $\gamma$ & AY795563 & 68 & $\begin{array}{l}\text { Fwd: AAGGGCTGTGATGTGTTTCTG } \\
\text { Rev: TGTACTGAGCGGCATTACTCC }\end{array}$ & TTGATGGGCTGGATGACTTTAGGA & 102.4 \\
\hline IL-1 $\beta$ & AJ223954 & 91 & $\begin{array}{l}\text { Fwd: ACATTGCCAACCTCATCATCG } \\
\text { Rev: TTGAGCAGGTCCTTGTCCTTG }\end{array}$ & CATGGAGAGGTTAAAGGGTGGC & 99.7 \\
\hline
\end{tabular}

Taq ReadyMixTM, $0.125 \mu \mathrm{l}$ ROX (diluted 10× in MilliQ water), 2 to $5.5 \mathrm{mM} \mathrm{MgCl}_{2}$ (all chemicals from Sigma-Aldrich), $0.5 \mu \mathrm{l}$ forward and reverse primer $(10 \mu \mathrm{M}), 0.5 \mu \mathrm{l}$ TaqMan ${ }^{\circledR}$ probe $(5 \mu \mathrm{M}), 2.5 \mu \mathrm{l}$ of diluted cDNA (1:10), and autoclaved MilliQ water to a volume of $12.5 \mu \mathrm{l}$. RT minus and negative controls (MilliQ water without template) were used for every plate setup. Elongation factor (EF)1- $\alpha$ primers and probes were used as endogenous controls (housekeeping gene) to correlate for potentially different loading amounts of RNA added to the Q-PCR reaction and for variation in CDNA synthesis efficiencies (Olsvik et al. 2005, Ingerslev et al. 2006). A high $C_{\mathrm{t}}$ value designates that the gene is expressed at a low level, and $1 C_{\mathrm{t}}$ value corresponds to a 2-fold difference in gene expression.

ELISA. An enzyme-linked immunosorbent assay (ELISA) was used to detect the presence of Yersinia ruckeri O1 specific IgM in plasma. The antigen, Yersinia ruckeri $\mathrm{O} 1$ (inactivated with $1 \%$ formaldehyde), was washed in PBS and resuspended $\left(1 \times 10^{7}\right.$ colony-forming units [CFU] well ${ }^{-1}, \mathrm{OD}_{600}=0.238$ with BIORAD SmartSpec TM 3000) in $100 \mu$ carbonate buffer (pH 9.6), and used for coating the wells (incubated at $4^{\circ} \mathrm{C}$ overnight) in microtiter plates (MaxiSorp, Nunc). Unbound bacteria were removed by 3 washes with $0.05 \%$ Tween-20 in PBS (pH 7.2; PBS-Tween), and the wells were subsequently blocked with $150 \mu \mathrm{ll} 1 \%$ bovine serum albumin (BSA) in PBS. Serial 2-fold dilu- tions (1:10 to 1:1280) of plasma in PBS with 0.1\% BSA (dilution buffer) were made in duplicate, and plasma samples were added to the wells and incubated at $4{ }^{\circ} \mathrm{C}$ overnight. The unbound plasma was then removed and followed by 3 washes with PBS-Tween. Rabbit anti-salmon Ig, which cross-reacts with rainbow trout Ig (Buchmann \& Pedersen 1994), diluted 1:1000 in dilution buffer was added (100 $\mu \mathrm{l}$ per well, $1 \mathrm{~h}$ incubation) and followed by 3 washes. Subsequently, $100 \mu \mathrm{l}$ peroxidase-conjugated goat anti-rabbit Ig (1:2000 in dilution buffer; Sigma) were supplied to each well. Following incubation for $1 \mathrm{~h}$ (followed by 6 washes) $100 \mu \mathrm{l}$ enzyme substrate o-phenylenediamine (OPD; KemEn-Tec Diagnostics A/S, Denmark) were added and the plates incubated for $10 \mathrm{~min}$ at $20^{\circ} \mathrm{C}$. The reaction was stopped using $100 \mu \mathrm{l} 1 \mathrm{M} \mathrm{H}_{2} \mathrm{SO}_{4}$, and the color development was measured spectrophotometrically at $492 \mathrm{~nm}$ using an ELISA-reader (Multiscan RC, type 351, Labsystems, Finland). Wells with all antibodies and substrates except sample material (primary antibody) were included as negative controls for the ELISA. Values greater than 2 times the background absorbance were considered positive.

Data analysis. $C_{\mathrm{t}}$ was determined at a fluorescence of 0.1 (arbitrary units of fluorescence) for all runs, taking care that this was at the linear slope in a log fluorescence/ $C_{\mathrm{t}}$ plot. The expression results were analyzed using the $2^{-\Delta \Delta C_{\mathrm{t}}}$ method (Livak \& Schmittgen 2001). Expression of all genes is relative 
to the gene expression of the 5 fish sampled pre-vaccination from each temperature, which was used as a calibrator (mean expression $=1$ ) whereby the PBSand bacterin-injected fish were compared to unhandled fish at the same temperature. The data are presented as the mean value of fold increase/decrease from 5 fish at a specific temperature and sampling time post-injection. The Mann-Whitney $U$-test was used to test for differences in plasma antibody titers determined by ELISA and relative transcription level (fold increase or decrease) between the PBS- or bacterin-injected fish at each temperature and sampling time. The correlation between the gene expression of secreted IgM and the actual plasma antibody titers were analyzed using the Spearman Rank Order correlation test. A probability level of $5 \%$ was applied in all tests.

\section{RESULTS}

\section{Expression of cytokines following immunization}

Low levels of constitutive expression of all examined genes in spleen and head kidney were detected, but a range of genes became up-regulated following immunization. The general trend of gene expression patterns of IL-1 $\beta$ and IL-10 in spleen and head kidney were very similar, showing higher levels in spleen compared to head kidney (Fig. 1, Tables $2 \& 3$ ). The $C_{\mathrm{t}}$ values for the constitutive expression of the relevant genes are shown in Table 4 to provide a general overview of the basic gene expression.

The IL-1 $\beta$ gene was significantly up-regulated in all immunized groups $4 \mathrm{~h}$ post immunization (hpi) in the spleen, and in both spleen and head kidney at $8 \mathrm{hpi}$. At
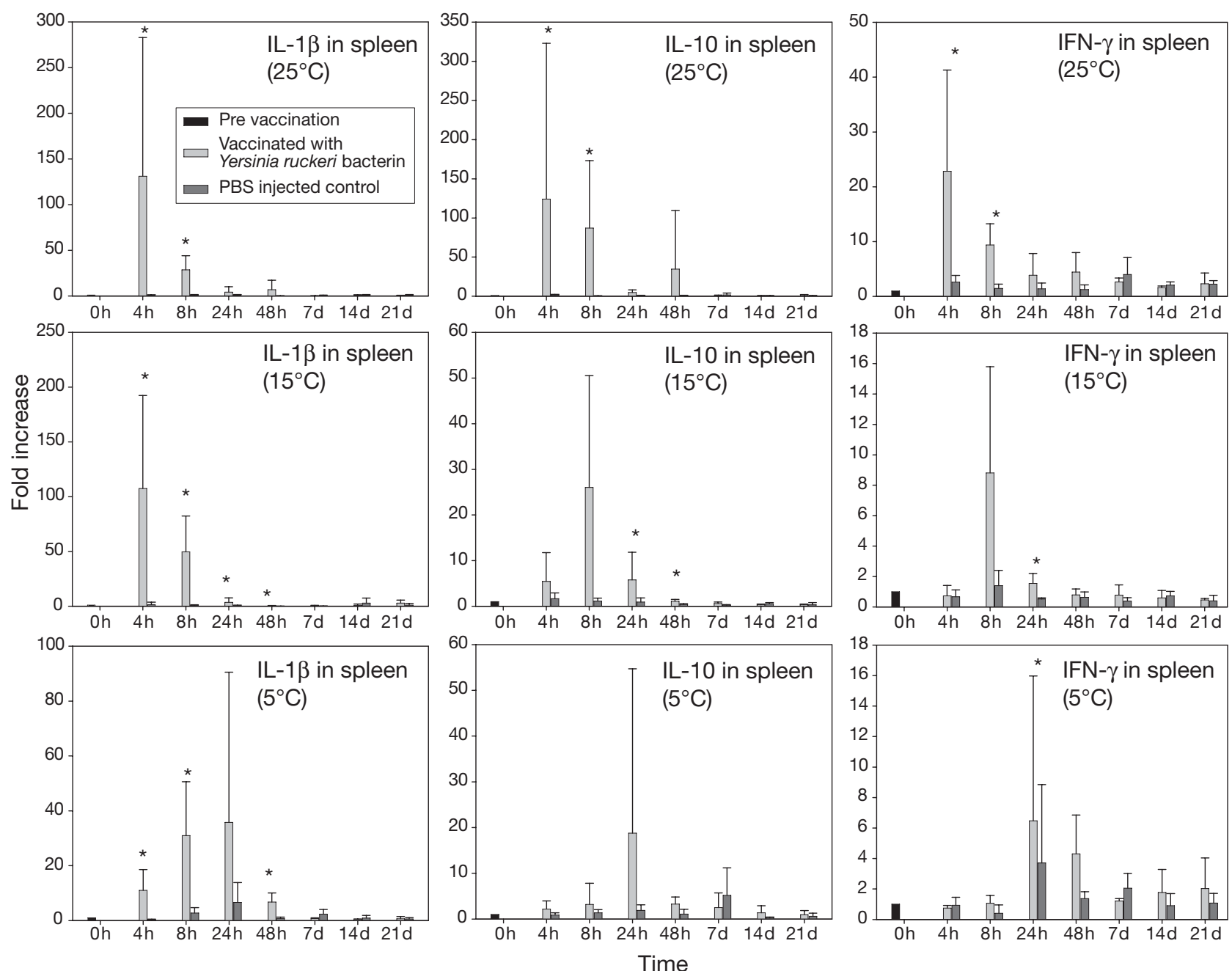

Fig. 1. Oncorhynchus mykiss. Real time quantitative expression of cytokines in the spleen following immunization with a bacterin of Yersinia ruckeri at 5, 15, and $25^{\circ} \mathrm{C}$ : (A) IL-1 $\beta$, (B) IL-10, (C) IFN- $\gamma$. Bars represent mean values ( \pm SD) of 5 fish per time point. Expression was compared to controls injected with PBS collected at the same time points. ${ }^{*}$ Significant up-regulation relative to control $(\mathrm{p}<0.05)$ 
$5^{\circ} \mathrm{C}$, there was a significant decrease of IL- $1 \beta$ expression in the spleen of the immunized group relative to the control group $7 \mathrm{~d}$ post immunization (dpi). The expression of the IL-10 gene was observed at significantly higher levels in immunized groups at 4 and $8 \mathrm{hpi}\left(25^{\circ} \mathrm{C}\right)$ in both head kidney and spleen, at 8 and $48 \mathrm{hpi}$ in head kidney, and at 24 and $48 \mathrm{hpi}$ in the spleen $\left(15^{\circ} \mathrm{C}\right)$. At $5^{\circ} \mathrm{C}$, the IL-10 gene was up-regulated at $48 \mathrm{hpi}$ in the head kidney, but there was no significant increase in the spleen (Fig. 1, Tables 2 \& 3).

IFN- $\gamma$ expression was significantly elevated following immunization, especially at higher temperatures. The IFN- $\gamma$ gene was significantly up-regulated at $4 \mathrm{hpi}$ in the spleen $\left(25^{\circ} \mathrm{C}\right)$, and in both spleen and head kidney 8 hpi $\left(25^{\circ} \mathrm{C}\right)$. At $5^{\circ} \mathrm{C}$, there was a significant decrease of IFN- $\gamma$ expression in the head kidney of the immunized group relative to the control group. At $24 \mathrm{hpi}$ IFN- $\gamma$ was significantly up-regulated in the spleen in the immunized group $\left(5\right.$ and $15^{\circ} \mathrm{C}$; Fig. 1 , Tables $2 \& 3)$. The TGF gene was significantly upregulated in the spleen $48 \mathrm{hpi}\left(25^{\circ} \mathrm{C}\right)$, in the head kidney $48 \mathrm{hpi}\left(5^{\circ} \mathrm{C}\right)$, and in the control group $7 \mathrm{dpi}$ $\left(25^{\circ} \mathrm{C}\right.$; Tables $\left.2 \& 3\right)$.

\section{Expression of genes encoding cellular receptors}

Expression of the C5aR gene in the spleen of immunized fish was significantly increased at 4 hpi (5 and $\left.25^{\circ} \mathrm{C}\right)$ and $8 \mathrm{hpi}\left(25^{\circ} \mathrm{C}\right)$. All immunized groups had higher expression 4 to 48 hpi than controls at 15 and $25^{\circ} \mathrm{C}$. The head kidney picture was less clear, exhibiting a significant up-regulation $4 \mathrm{hpi}\left(5^{\circ} \mathrm{C}\right)$ and $7 \mathrm{dpi}$ $\left(15^{\circ} \mathrm{C}\right)$ with the control group showing a significant increase at $21 \mathrm{dpi}$. The MHC II gene was not significantly regulated following immunization, neither in spleen nor head kidney, at any of the 3 temperatures (Tables 2 \& 3). Further, we noted a significant decrease of T-cell receptor gene expression in the spleen of immunized fish at $24 \mathrm{hpi}\left(15^{\circ} \mathrm{C}\right)$ and $48 \mathrm{hpi}\left(5^{\circ} \mathrm{C}\right)$. No regulation was seen in the head kidney.

\section{Immunoglobulin gene expression and production}

The gene encoding IgT was generally expressed at a low level but was significantly up-regulated in spleen of the control group fish at 4 and $48 \mathrm{hpi}$ and $14 \mathrm{dpi}$ $\left(5^{\circ} \mathrm{C}\right)$. No regulation was seen in the head kidney or at other temperatures. Genes encoding secreted IgM were not regulated in the spleen, but a significant increase of expression was seen at $21 \mathrm{dpi}$ in the head kidney at $25^{\circ} \mathrm{C}$ (Tables $2 \& 3$ ). In addition, the expression at this temperature was positively correlated $(\mathrm{r}=$ 0.663, $p=0.00273$ ) to the plasma titers measured by
ELISA (Table 5). The highest titers were generally found at $21 \mathrm{dpi}$ in fish reared at $25^{\circ} \mathrm{C}$. Further, bacterin-injected fish exhibited significantly higher titers at $25^{\circ} \mathrm{C}$ and $15^{\circ} \mathrm{C}$ compared to $5^{\circ} \mathrm{C}$ (14 and $\left.21 \mathrm{dpi}\right)$, although immunized fish also exhibited significantly higher titers than PBS-injected fish at 7 dpi even at $5^{\circ} \mathrm{C}$. Various factors showed a confounding effect on the experiment. It should be noted that PBS-injection was followed by a slight up-regulation of antibodyproduction, and an effect of water temperature on the antibody production in non-immunized fish was found as well. Thus, antibody titers in the PBS-injected group were significantly higher at $25^{\circ} \mathrm{C}$ compared to the PBSinjected groups reared at $15^{\circ} \mathrm{C}$ and $5^{\circ} \mathrm{C}$ (all samplings). Likewise, titers at $15^{\circ} \mathrm{C}$ were higher compared to $5^{\circ} \mathrm{C}$ (14 and $21 \mathrm{dpi}$ ).

\section{DISCUSSION}

This investigation has shown that injection of a Yersinia ruckeri bacterin into the peritoneal cavity of rainbow trout induces a series of immunological events including cytokine gene expression, expression of cellular receptor genes, and immunoglobulin production. Further, our work has validated the notion that these reactions are temperature dependent. Our investigation included temperatures ranging from a suboptimal level $\left(5^{\circ} \mathrm{C}\right)$ via the physiological optimum $\left(15^{\circ} \mathrm{C}\right)$ to a near lethal temperature $\left(25^{\circ} \mathrm{C}\right)$, which is normally considered too high for trout (Matthews \& Berg 1997). It was previously noted that injection of a Y. ruckeri bacterin causes inflammation in the peritoneal cavity of rainbow trout involving migration of leukocytes from the capillaries into the affected tissue. A rapid influx of neutrophils, peaking at 24 to 48 hpi was described at the site during inflammation (Afonso et al. 1998). Leukocytes in rainbow trout are able to take up i.p.injected bacteria by phagocytosis, and this process is enhanced if the bacteria are opsonized either by complement or by IgM (Li et al. 2006). Some of the molecular elements involved in this process may have been reflected in the present work. Thus, the extensive cytokine expression during the first $2 \mathrm{~d}$ after injection seems to be part of the early host reaction to the bacterin. The up-regulated IL-1 $\beta$ and IL-10 gene expression was more pronounced in the spleen compared to the head kidney. This could be due to more extensive inflammatory processes in the peritoneal cavity, where the spleen is situated and the bacterin was injected. Furthermore, injection of $Y$. ruckeri leads to migration of large granular cells from the anterior kidney to the spleen (Welch \& Wiens 2005), which supports these findings. Bacterial lipopolysaccharide (LPS) or synthetic oligo-deoxynucleotides (ODNs) mimicking bac- 


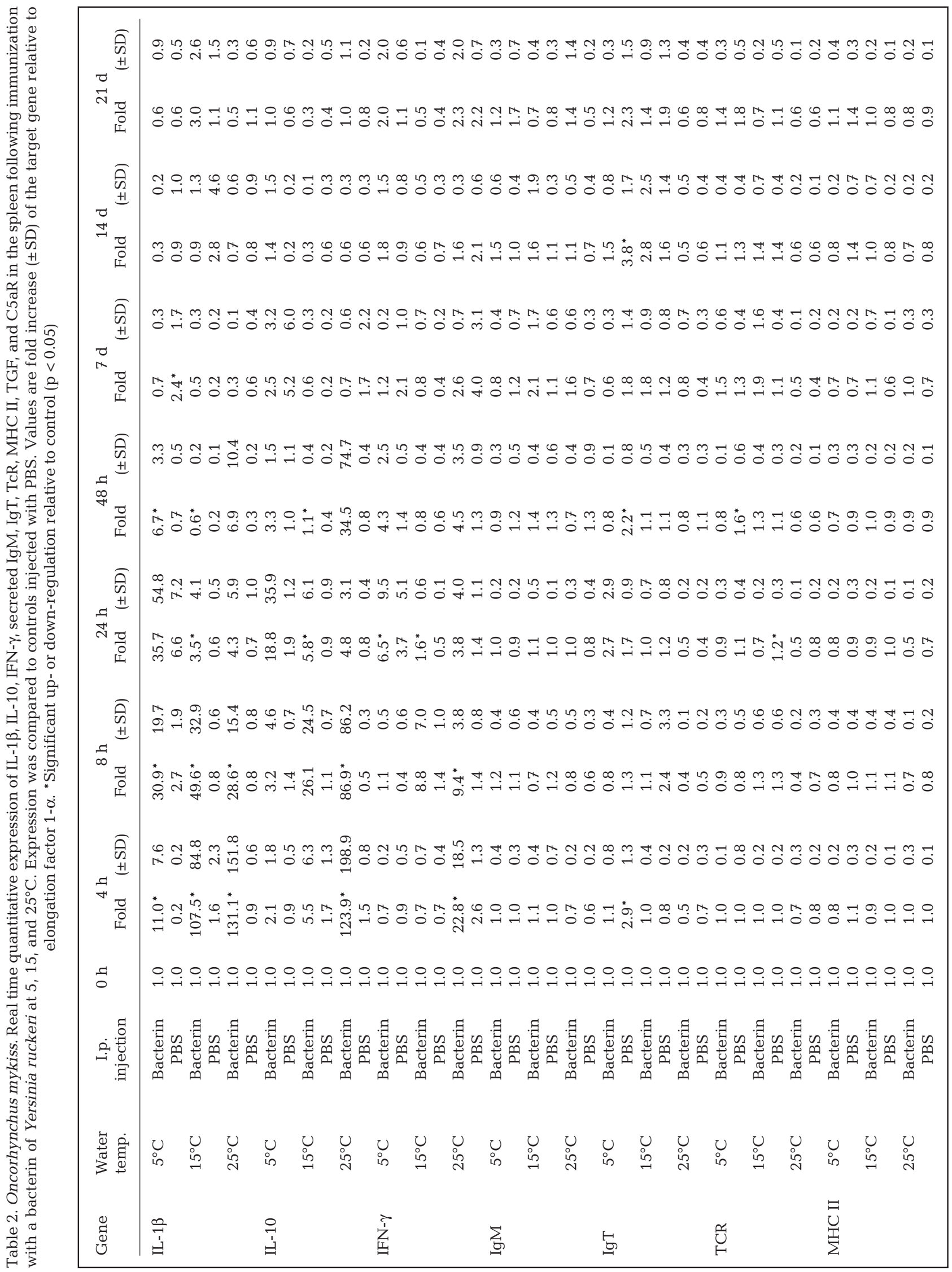




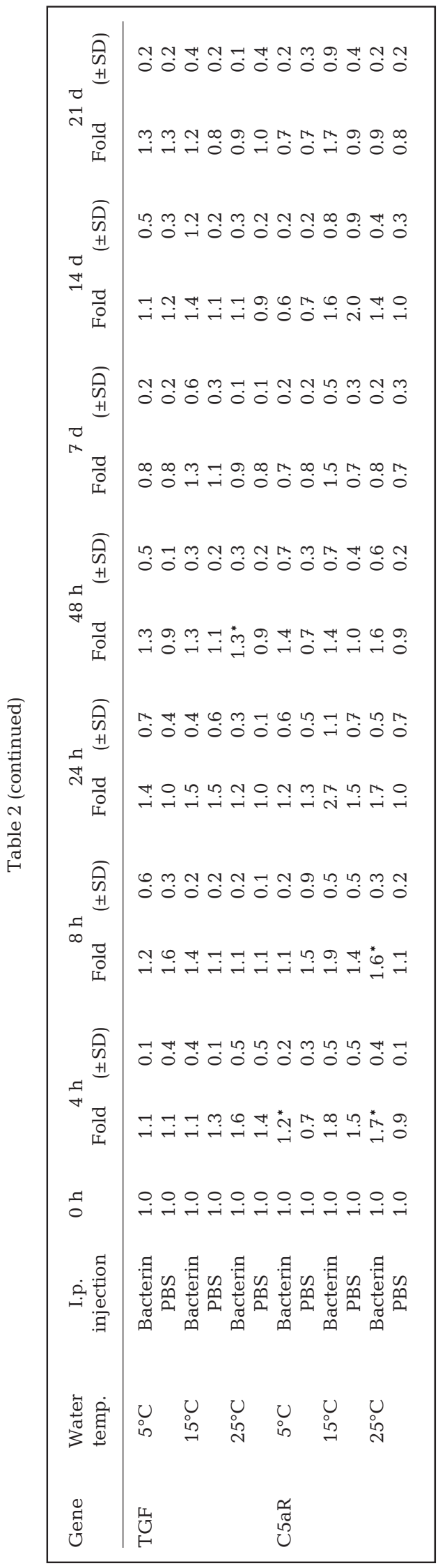

terial DNA stimulate rainbow trout head-kidney macrophages to induce IL-1 $\beta$ expression and stimulate peripheral blood (PBL), spleen, and head-kidney lymphocytes to proliferate (Jørgensen et al. 2001, Goetz et al. 2004). This cytokine is a potent pro-inflammatory molecule in fish (Lindenstrøm et al. 2004), and it increases leukocyte migration in rainbow trout (Hong et al. 2003). Our work supports this suggested path of immunological events and further indicates that these immune reactions occur faster and at a higher rate at high temperatures. Because IL-8 is considered to have a chemoattractive effect on neutrophils (Zhang et al. 2002), it would be relevant in future studies to include tissue from the peritoneal cavity (peritoneal cells and peritoneal exudate cells) and study the expression of the IL-8 gene following bacterin injection.

The role and function of IL-10 in trout is less clearly established. The up-regulation of IL-10 was as high as 124 and 87 times in spleen and up to 12 and 18 times in head kidney relative to unstimulated control fish at 4 and $8 \mathrm{hpi}$, respectively. This corresponds to other studies indicating an extensive up-regulation of IL-10 expression in a number of fishes after LPS stimulation (Savan et al. 2003, Inoue et al. 2005, Zhang et al. 2005). In mammals, IL-10 can act as a cytokine inhibitory factor and demonstrates immune-suppressive functions that could minimize damage to the host tissue induced by response to a pathogen (Hummelshoj et al. 2006). However, the cytokine is now believed to act as a pleiotropic cytokine with multiple biological effects, one of them positively affecting the production of immunoglobulin by B cells (Hummelshoj et al. 2006). Further, IL-10 is able to inhibit IFN- $\gamma$ production by Th1 cells, production of nitric oxide, and pro-inflammatory cytokines by macrophages, which can skew the immune response from Th1 to Th2 (Zou et al. 2003; Inoue et al. 2005). Upregulation of IL-10 would therefore be expected to follow expression of pro-inflammatory cytokines like IL-1 $\beta$. However, we did not see a delay between upregulation of pro-inflammatory cytokines and IL-10 expression as was previously found in mammals (Härtel et al. 1999). The role of IL-10 in trout is therefore still less well established due to the fact that we could not point to a clear regulating effect of this cytokine. This suggests that future studies should address the role of IL-10 in further detail. The cytokine TGF generally occurs at later stages in the inflammatory process, which could indicate a regulating or anti-inflammatory action corresponding to the late expression in rainbow trout infected with ectoparasites (Lindenstrøm et al. 2003) or DNA vaccinated with viral glycoprotein (Jimenez et al. 2006). IFN- $\gamma$ was generally highly up-regulated in immunized fish, especially at higher temperatures. It is synthesized and secreted by 


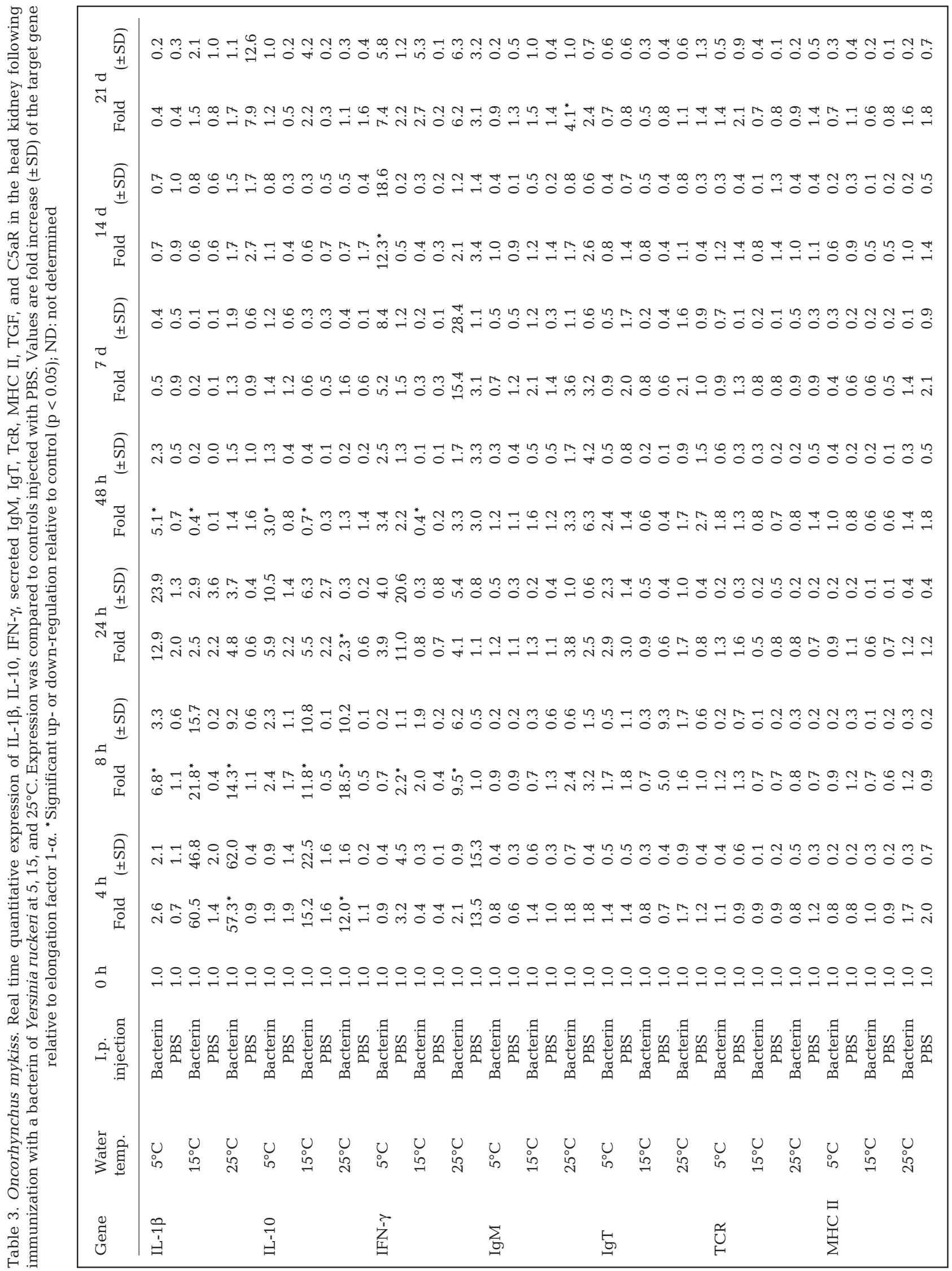




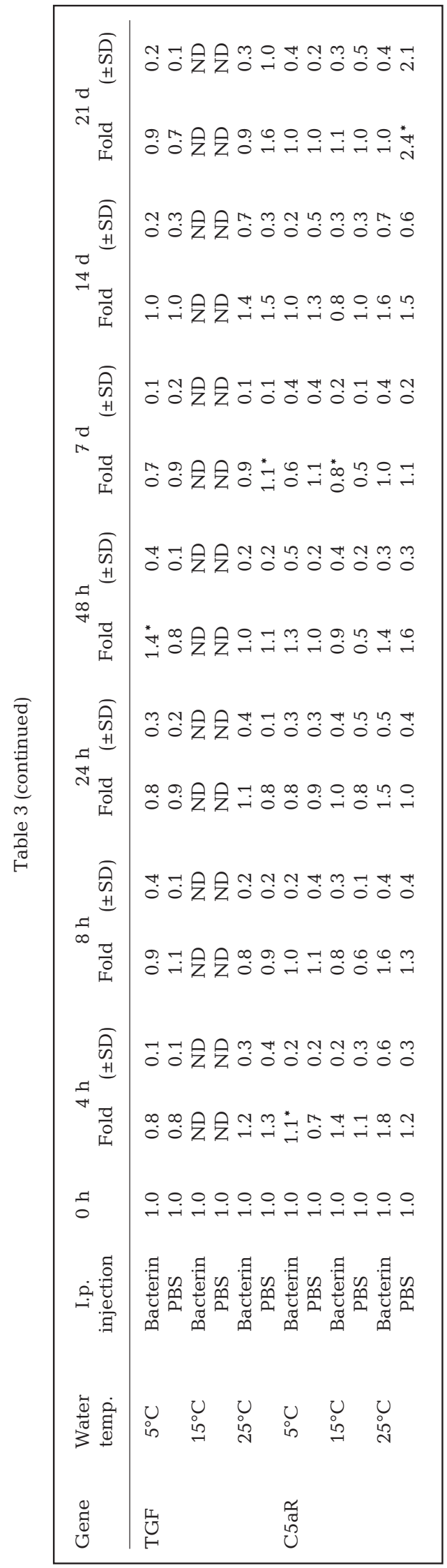

T-cells and NK-cells (Boehm et al. 1997), and is considered to act as a pro-inflammatory cytokine (Dinarello 2000). Recombinant IFN- $\gamma$ increases gene expression of IFN- $\gamma$-inducible protein 10, MHC II beta-chain, and STAT1 and enhances respiratory burst activity in macrophages from head kidney of rainbow trout (Zou et al. 2005). The marked IFN- $\gamma$ increase in head kidney and spleen found in the present study suggests that cellular elements of the trout immune response are activated by the extra-cellular Yersinia ruckeri bacterin. In fact, the gene encoding the cellular C5a receptor was up-regulated. This receptor is found on phagocytes taking part in elimination of pathogens. Following activation of the complement system, the C5a component of the activated complement has a chemotactic effect on fish phagocytes. The effects of C5a are mediated by its binding to $\mathrm{C} 5 \mathrm{a}$ receptor (C5aR, CD88) expressed on B lymphocytes and granulocytes (Boshra et al. 2004) and macrophages (Holland \& Lambris 2004, Sunyer et al. 2005), which all have phagocytic functions in trout (Sunyer et al. 2005, Li et al. 2006). In fact, generation of complement activated plasma that contains C5a increases phagocytosis in rainbow trout head-kidney cells 3 to 4 fold (Li et al. 2004). Previous studies have shown that the lytic activity of complement in rainbow trout is higher in fish acclimated at $20^{\circ} \mathrm{C}$ compared to 5 and $10^{\circ} \mathrm{C}$ (Nikoskelainen et al. 2002, 2004). Therefore, is it likely that more C5a will be generated in fish reared at high water temperature. We found a significant increase in $\mathrm{C} 5 \mathrm{aR}$ expression in fish at $25^{\circ} \mathrm{C}$, which supports the notion of an increased level of this arm of the immune system at higher temperatures. MHC class II receptors are expressed on the surface of antigen-presenting cells (Nath et al. 2006), and increased expression of MHC II in the spleen and gills has been recorded after vaccination of salmon (Koppang et al. 1998). However, we could not detect changes of MHC II expression in spleen and head kidney following immunization. Injection of recombinant IL-1, and recombinant IFN- $\gamma$ increases the expression of MHC II in rainbow trout cells (Hong et al. 2003, Zou et al. 2005), but the increase of IL-1, and IFN- $\gamma$ gene expression found in our investigation was not associated with a detectable MHC II increase. However, this does not necessarily imply that MHC II is not involved in the reaction. The MHC II molecules present on antigen-presenting cells in our experimental trout (even pre-vaccination) could be sufficient for the needed antigen presentation.

TcR is a measure of T-cell occurrence in the tissue and may therefore monitor in- and out-flux (migration) of T-cells. It seems that there is a lower expression of TcR in the spleen following immunization, which could be interpreted as T-cell depletion with cells leaving the 
Table 4. Oncorhynchus mykiss. Basic $C_{\mathrm{t}}$ values for constitutive expressions of the immune-relevant genes studied in head kidney and spleen of unhandled fish. ND: not determined

\begin{tabular}{|c|c|c|c|c|c|}
\hline \multirow[t]{2}{*}{ Gene } & \multirow{2}{*}{$\begin{array}{l}\text { Water } \\
\text { temp. }\end{array}$} & \multicolumn{2}{|c|}{ Head kidney } & \multicolumn{2}{|c|}{ Spleen } \\
\hline & & $C_{\mathrm{t}}$ value & $\mathrm{SD}$ & $C_{\mathrm{t}}$ value & SD \\
\hline \multirow[t]{3}{*}{ IL-1 $\beta$} & $5^{\circ} \mathrm{C}$ & 31.3 & 0.7 & 31.4 & 1 \\
\hline & $15^{\circ} \mathrm{C}$ & 33.6 & 1.1 & 31.0 & 0.8 \\
\hline & $25^{\circ} \mathrm{C}$ & 32.4 & 0.6 & 32.2 & 0.4 \\
\hline \multirow[t]{3}{*}{ IL-10 } & $5^{\circ} \mathrm{C}$ & 35.6 & 1.3 & 33.2 & 1.8 \\
\hline & $15^{\circ} \mathrm{C}$ & 33.4 & 0.6 & 33.1 & 0.7 \\
\hline & $25^{\circ} \mathrm{C}$ & 33.8 & 0.4 & 34.4 & 1 \\
\hline \multirow[t]{3}{*}{ IFN- $\gamma$} & $5^{\circ} \mathrm{C}$ & 34.2 & 1.1 & 33.3 & 1.1 \\
\hline & $15^{\circ} \mathrm{C}$ & 34.5 & 1 & 31.9 & 1.2 \\
\hline & $25^{\circ} \mathrm{C}$ & 34.2 & 1.1 & 33.4 & 1.4 \\
\hline \multirow[t]{3}{*}{$\operatorname{Ig} M$} & $5^{\circ} \mathrm{C}$ & 22.4 & 0.67 & 22.7 & 0.4 \\
\hline & $15^{\circ} \mathrm{C}$ & 24.2 & 0.9 & 22.7 & 0.3 \\
\hline & $25^{\circ} \mathrm{C}$ & 21.5 & 0.3 & 21.2 & 0.7 \\
\hline \multirow[t]{3}{*}{$\operatorname{IgT}$} & $5^{\circ} \mathrm{C}$ & 28.9 & 0.9 & 28.7 & 1.3 \\
\hline & $15^{\circ} \mathrm{C}$ & 29.3 & 1 & 27.2 & 1 \\
\hline & $25^{\circ} \mathrm{C}$ & 28.5 & 1.3 & 28.2 & 1.2 \\
\hline \multirow[t]{3}{*}{ TCR } & $5^{\circ} \mathrm{C}$ & 28.0 & 1.1 & 28.2 & 1 \\
\hline & $15^{\circ} \mathrm{C}$ & 28.9 & 1.2 & 26.7 & 0.6 \\
\hline & $25^{\circ} \mathrm{C}$ & 26.4 & 0.4 & 26.3 & 0.9 \\
\hline \multirow[t]{3}{*}{ MHC II } & $5^{\circ} \mathrm{C}$ & 24.7 & 0.6 & 23.4 & 0.8 \\
\hline & $15^{\circ} \mathrm{C}$ & 25.5 & 0.9 & 22.0 & 0.5 \\
\hline & $25^{\circ} \mathrm{C}$ & 24.2 & 0.4 & 22.4 & 0.8 \\
\hline \multirow[t]{3}{*}{ TGF } & $5^{\circ} \mathrm{C}$ & 27.0 & 0.8 & 28.2 & 1 \\
\hline & $15^{\circ} \mathrm{C}$ & ND & ND & 27.6 & 0.4 \\
\hline & $25^{\circ} \mathrm{C}$ & 27.0 & 0.2 & 27.8 & 0.9 \\
\hline \multirow[t]{3}{*}{ C5aR } & $5^{\circ} \mathrm{C}$ & 25.1 & 0.9 & 25.6 & 0.6 \\
\hline & $15^{\circ} \mathrm{C}$ & 27.7 & 0.6 & 26.6 & 0.6 \\
\hline & $25^{\circ} \mathrm{C}$ & 26.3 & 0.23 & 26.3 & 0.5 \\
\hline \multirow[t]{3}{*}{ EF1- $\alpha$} & $5^{\circ} \mathrm{C}$ & 24.6 & 1.1 & 23.7 & 0.6 \\
\hline & $15^{\circ} \mathrm{C}$ & 24.6 & 0.5 & 22.5 & 0.5 \\
\hline & $25^{\circ} \mathrm{C}$ & 21.5 & 0.1 & 22.5 & 0.5 \\
\hline
\end{tabular}

Table 5. Oncorhynchus mykiss. Antibody titers $( \pm \mathrm{SD})$ in plasma of fish immunized using a Yersinia ruckeri bacterin at 3 temperature levels evaluated by ELISA. Two-fold dilutions of plasma were used. Five fish per time point. *: Significantly higher antibody titers in bacterin-injected fish compared to PBSinjected fish at the same water temperature and sampling time post injection. $\S$ : Significantly higher antibody titers compared to other groups injected with the same substance (bacterin or PBS), at the same sampling time post injection, but at different water temperatures. \#: Significantly higher antibody titers in PBS-injected fish than in the group sampled pre-injection at the same water temperature

\begin{tabular}{|lcclll|}
\hline $\begin{array}{l}\text { Water } \\
\text { temp. }\end{array}$ & $\begin{array}{c}\text { Ip inj. with } \\
\text { bacterin or } \\
\text { PBS (control) }\end{array}$ & $0 \mathrm{~h}$ & $7 \mathrm{~d}$ & $14 \mathrm{~d}$ & $21 \mathrm{~d}$ \\
\hline $5^{\circ} \mathrm{C}$ & Bacterin & $3.93(1.34)$ & $7.53(0.84)^{*}$ & $3.93(1.34)$ & $3.33(0.00)$ \\
& Control & & $3.73(0.55)$ & $3.33(0.00)$ & $3.73(0.55)$ \\
$15^{\circ} \mathrm{C}$ & Bacterin & $3.53(0.45)$ & $6.53(0.84)^{*}$ & $7.73(2.07) \S$ & $5.73(2.30)$ \\
& Control & & $4.33(1.41)$ & $5.93(0.89) \S \#$ & $5.33(1.22)$ \\
$25^{\circ} \mathrm{C}$ & Bacterin & $6.33(1.00) \S$ & $8.73(1.52) \S$ & $8.73(2.07) \S$ & $10.33(0.00) \S$ \\
& Control & & $7.93(1.34) \S$ & $8.53(1.79) \S$ & $9.33(1.41) \S \#$ \\
& & & & & \\
\hline
\end{tabular}

spleen 8 to $48 \mathrm{hpi}$. This process works faster and more extensively at higher temperatures. No regulation was seen in the head kidney, which complies with other infection studies in trout (Lindenstrøm et al. 2004). However, to follow cellular dynamics in a host, future studies should include expression levels of peripheral blood cells as well.

$\operatorname{Ig} \mathrm{T}$ is a teleost-specific antibody with unknown function (Hansen et al. 2005), and it was very weakly expressed even after immunization. Compared to IgM, the expression level of IgT mRNA was extremely low. The primers used for measuring $\operatorname{IgM}$ mRNA were designed in the $\mu 4$ domain and are specific for the secreted form of IgM because membrane bound IgM lacks the $\mathrm{CH} 4$ domain in rainbow trout (Andersson \& Matsunaga 1993). There was a significant increase in mRNA coding for IgM in the head kidney $21 \mathrm{dpi}$ at $25^{\circ} \mathrm{C}$. This moderate increase of IgM expression may be explained by the fact that Yersinia ruckeri-specific mRNA merely represents a limited fraction of the total mRNA encoding secreted IgM. The significantly increased level of mRNA encoding secreted IgM in the head kidney of immunized fish was correlated to the increase of specific IgM measured by ELISA at the same time. Thus the results support the notion that the late antibody response is mainly caused by Ig secretion from plasma cells in the anterior kidney (Bromage et al. 2004). The observed titer increase could be due to both an increased amount of antibodies and to increased affinity of the antibody. Thus, antibody affinity can increase 2to 3 -fold during the course of the immune response in trout (Cain et al. 2002) but this question is still unresolved in the present work. Our results showing a higher level of antibodies in naive fish reared at $25^{\circ} \mathrm{C}$, compared to 5 and $15^{\circ} \mathrm{C}$, correspond to previous work detecting temperature-dependent production of natural immunoglobulin in rainbow trout (Suzuki et al. 1997, Nikoskelainen et al. 2004). How- 
ever, it is noteworthy that PBS-injected control fish also showed an increase (albeit low) of antibody production. This increase was not seen at the mRNA level.

The present investigation focused on the expression of immune relevant genes in the vaccinated host but did not evaluate protection. However, it was shown that both the cytokine response and development of antibodies are working at low levels at low water temperatures. This could explain why low water temperature can be the cause of immunization failure against ERM (Rodgers 1991) and why protective immunity in rainbow trout against Yersinia ruckeri is temperature dependent (Johnson et al. 1982). Further, the work emphasizes that temperature is an important abiotic parameter for developing immunity in ectothermic vertebrates, such as rainbow trout, and it is noteworthy that no depression of gene expression (as judged from the studied genes) could be detected even at temperatures near the upper lethal limit of rainbow trout. However, our investigation focused on expression of a limited number of immune-relevant genes, and it is likely that other genes and factors are involved in protection of rainbow trout against ERM. Therefore, further studies should investigate additional genes (including CD4, CD8, and IL-8) and describe the influence of temperature on the functional immune response (protection of trout against challenge infections with $Y$. ruckeri).

Acknowledgements. This investigation was supported as part of the integrated research project Improved Immunity of Aquacultured Animals (IMAQUANIM) sponsored by the European Commission (EU) and by a grant to the project 'Welfare in farmed rainbow trout' from the Danish Ministry for Food. The authors are indebted to Dr. B. Brudeseth (Pharmaq, Norway) for delivering the vaccine and to H. C. Ingerslev (University of Bergen, Norway) for valuable instruction and advice.

\section{LITERATURE CITED}

Afonso A, Lousada S, Silva J, Ellis AE, Silva MT (1998) Neutrophil and macrophage responses to inflammation in the peritoneal cavity of rainbow trout Oncorhynchus mykiss. A light and electron microscopic cytochemical study. Dis Aquat Org 34(1):27-37

Afonso A, Oliveira C, Ellis AE (1999) Peroxidase activity as a measure of neutrophil populations in inflammatory peritoneal exudates of rainbow trout, Oncorhynchus mykiss (Walbaum). J Fish Dis 22(2):133-142

Andersson E, Matsunaga T (1993) Complete cDNA sequence of rainbow trout IgM gene and evolution of vertebrate IgM constant domains. Immunogenetics 38(4):243-250

Boehm U, Klamp T, Groot M, Howard JC (1997) Cellular responses to interferon-gamma. Annu Rev Immunol 15: 749-795

Boshra H, Li J, Peters R, Hansen J, Matlapudi A, Sunyer JO (2004) Cloning, expression, cellular distribution, and role in chemotaxis of a $\mathrm{C} 5 \mathrm{a}$ receptor in rainbow trout: the first identification of a C5a receptor in a non-mammalian species. J Immunol 172(7):4381-4390

Bromage ES, Kaattari IM, Zwollo P, Kaattari SL (2004) Plasmablast and plasma cell production and distribution in trout immune tissues. J Immunol 173(12):7317-1723

Buchmann K, Pedersen K (1994) A study on teleost phylogeny using specific antisera. J Fish Biol 45(5):901-903

Cain KD, Jones DR, Raison RL (2002) Antibody-antigen kinetics following immunization of rainbow trout (OnCorhynchus mykiss) with a T-cell dependent antigen. Dev Comp Immunol 26(2):181-190

Cossarini-Dunier M (1986) Protection against enteric redmouth disease in rainbow trout, Salmo gairdneri Richardson, after vaccination with Yersinia ruckeri bacterin. J Fish Dis 9(1):27-33

Dinarello CA (2000) Proinflammatory cytokines. Chest 118(2):503-508

Goetz FW, Iliev DB, McCauley LA, Liarte CQ, Tort LB, Planas JV, Mackenzie S (2004) Analysis of genes isolated from lipopolysaccharide-stimulated rainbow trout (Oncorhynchus mykiss) macrophages. Mol Immunol 41(12): 1199-1210

Hansen JD, Landis ED, Phillips RB (2005) Discovery of a unique Ig heavy-chain isotype (IgT) in rainbow trout: implications for a distinctive B cell developmental pathway in teleost fish. Proc Natl Acad Sci USA 102(19): 6919-6924

Härtel C, Bein G, Kirchner H, Kluter H (1999) A human whole-blood assay for analysis of T-cell function by quantification of cytokine mRNA. Scand J Immunol 49(6): $649-654$

Holland MCH, Lambris JD (2004) A functional C5a anaphylatoxin receptor in a teleost species. J Immunol 172(1): 349-355

Hong S, Peddie S, Campos-Perez JJ, Zou J, Secombes CJ (2003) The effect of intraperitoneally administered recombinant IL-1beta on immune parameters and resistance to Aeromonas salmonicida in the rainbow trout (Oncorhynchus mykiss). Dev Comp Immunol 27(9): 801-812

Hummelshoj L, Ryder LP, Poulsen LK (2006) The role of the interleukin-10 subfamily members in immunoglobulin production by human B cells. Scand J Immunol 64(1): $40-47$

Ingerslev HC, Pettersen EF, Jakobsen RA, Petersen CB, Wergeland HI (2006) Expression profiling and validation of reference gene candidates in immune relevant tissues and cells from Atlantic salmon (Salmo salar L.). Mol Immunol 43(8):1194-1201

Inoue $\mathrm{Y}$, Kamota $\mathrm{S}$, Ito $\mathrm{K}$, Yoshiura $\mathrm{Y}$, Ototake M, Moritomo T, Nakanishi T (2005) Molecular cloning and expression analysis of rainbow trout (Oncorhynchus mykiss) interleukin-10 cDNAs. Fish Shellfish Immunol 18(4):335-344

Jimenez N, Coll J, Salguero FJ (2006) Co-injection of interleukin 8 with the glycoprotein gene from viral haemorrhagic septicemia virus (VHSV) modulates the cytokine response in rainbow trout (Oncorhynchus mykiss). Vaccine 24(27-28):5615-5626

Johnson KA, Amend DF (1983) Comparison of efficacy of several delivery methods using Yersinia ruckeri bacterin on rainbow trout (Salmo gairdneri, Richardson). J Fish Dis 6(4):331-336

Johnson KA, Flynn JK, Amend DF (1982) Onset of immunity in salmonid fry vaccinated by direct immersion in Vibrio anguillarum and Yersinia ruckeri bacterins. J Fish Dis 5(3):197-205 
Jørgensen JB, Zou J, Johansen A, Secombes CJ (2001) Immunostimulatory $\mathrm{CpG}$ oligodeoxynucleotides stimulate expression of IL-1 beta and interferon-like cytokines in rainbow trout macrophages via a chloroquine-sensitive mechanism. Fish Shellfish Immunol 11(8):673-682

Koppang EO, Lundin M, Press CM, Rønningen K, Lie Ø (1998) Differing levels of Mhc class II beta chain expression in a range of tissues from vaccinated and non-vaccinated Atlantic salmon (Salmo salar L.) Fish Shellfish Immunol 8(3):183-196

Li J, Peters R, Lapatra S, Vazzana M, Sunyer JO (2004) Anaphylatoxin-like molecules generated during complement activation induce a dramatic enhancement of particle uptake in rainbow trout phagocytes. Dev Comp Immunol 10:1005-1021

Li J, Barreda DR, Zhang YA, Boshra H, Gelman AE, Lapatra S, Tort L, Sunyer JO (2006) B lymphocytes from early vertebrates have potent phagocytic and microbicidal abilities. Nat Immunol 7(10):1116-1124

Lindenstrøm T, Buchmann K, Secombes CJ (2003) Gyrodactylus derjavini infection elicits IL-1 beta expression in rainbow trout skin. Fish Shellfish Immunol 15:107-115

Lindenstrøm T, Secombes CJ, Buchmann K (2004) Expression of immune response genes in rainbow trout skin induced by Gyrodactylus derjavini infections. Vet Immunol Immunopathol 97:137-148

Livak KJ, Schmittgen TD (2001) Analysis of relative gene expression data using real-time quantitative PCR and the 2(-Delta Delta C(T)). Methods 25(4):402-408

Matthews KR, Berg NH (1997) Rainbow trout responses to water temperature and dissolved oxygen stress in two southern California stream pools. J Fish Biol 50(1):50-67

Nath S, Kales S, Fujiki K, Dixon B (2006) Major histocompatibility class II genes in rainbow trout (Oncorhynchus mykiss) exhibit temperature dependent downregulation. Immunogenetics 58(5-6):443-453

Nikoskelainen S, Lehtinen J, Lilius EM (2002) Bacteriolytic activity of rainbow trout (Oncorhynchus mykiss) complement. Dev Comp Immunol 26(9):797-804

Nikoskelainen S, Bylund G, Lilius EM (2004) Effect of environmental temperature on rainbow trout (Oncorhynchus mykiss) innate immunity. Dev Comp Immunol 28(6): 581-592

Editorial responsibility: Catherine Collins,

Aberdeen, UK
Olsvik PA, Lie KK, Jordal AE, Nilsen TO, Hordvik I (2005) Evaluation of potential reference genes in real-time RT-PCR studies of Atlantic salmon. BMC Mol Biol (17):6-21

Rodgers CJ (1991) The usage of vaccination and antimicrobial agents for control of Yersinia ruckeri. J Fish Dis 14(3): 291-301

Savan R, Igawa D, Sakai M (2003) Cloning, characterization and expression analysis of interleukin-10 from the common carp, Cyprinus carpio L. Eur J Biochem 270(23): 4647-4654

Stevenson RMW (1997) Immunization with bacterial antigens: Yersiniosis Dev Biol Stand 90:117-124

Sunyer JO, Boshra H, Li J (2005) Evolution of anaphylatoxins, their diversity and novel roles in innate immunity: Insights from the study of fish complement. Vet Immunol Immunopathol 108(1-2):77-89

Suzuki Y, Otaka T, Sato S, Hou YY, Aida K (1997) Reproduction related immunoglobulin changes in rainbow trout. Fish Physiol Biochem 17(1-6):415-421

Welch TJ, Wiens GD (2005) Construction of a virulent, green fluorescent protein-tagged Yersinia ruckeri and detection in trout tissues after intraperitoneal and immersion challenge. Dis Aquat Org 67(3):267-272

Zhang H, Thorgaard GH, Ristow SS (2002) Molecular cloning and genomic structure of an interleukin-8 receptor-like gene from homozygous clones of rainbow trout (Oncorhynchus mykiss). Fish Shellfish Immunol 13(3): 251-258

Zhang DC, Shao YQ, Huang YQ, Jiang SG (2005) Cloning, characterization and expression analysis of interleukin-10 from the zebrafish (Danio rerio). J Biochem Mol Biol 38(5): 571-576

Zou J, Clark MS, Secombes CJ (2003) Characterisation, expression and promoter analysis of an interleukin 10 homologue in the puffer fish, Fugu rubripes. Immunogenetics 55(5):325-335

Zou J, Carrington A, Collet B, Dijkstra JM, Yoshiura Y, Bols N, Secombes C (2005) Identification and bioactivities of IFNgamma in rainbow trout Oncorhynchus mykiss: The first Th1-type cytokine characterized functionally in fish. J Immunol 175(4):2484-2494

Submitted: January 19, 2007; Accepted: April 2, 2007 Proofs received from author(s): August 6, 2007 